\title{
Comparison of DNA Extraction Methods Between Conventional, Kit, Alkali and Buffer-Only for PCR Amplification on Raw and Boiled Bovine and Porcine Meat
}

\author{
Arif Yahya*, Marindra Firmansyah, Annisa Arlisyah, Rio Risandiansyah \\ Medical Faculty, Islamic University of Malang, Malang, Indonesia
}

\begin{abstract}
Detection of porcine contamination in food material by employing PCR techniques is integral in halal food confirmation. However, PCR is both costly and laborious, particularly in DNA isolation method. This study explores several different methods in DNA extraction for PCR amplification in bovine and porcine raw and boiled meat samples. Four methods for DNA extraction (conventional PCI method, DNA isolation kit, alkaline-based method, and a DNA lysis buffer-only from the same kit) was employed followed by PCR using primers from previous studies and compared for DNA quality and quantity (in six replicates) and PCR amplification on the best three DNA samples. This study shows that in all samples, the conventional method had the best DNA yield based on nanodrop measurement, followed by an alkali-based method, buffer-only method, and DNA isolation kit. Each method except lysis-buffer only had at least one sample with good DNA quality. Conventional and isolation kit showed reliable positive PCR detection for all porcine and bovine samples (92\% positive). Using the alkaline-lysis method, DNA was amplified reliably on boiled meat samples (83\% positive). Lysis-buffer-only method did not show consistent PCR amplification on the samples used (50\% positive). The conclusion was that conventional PCI method and DNA isolation kit showed high reliability in PCR amplification of bovine and porcine meats, both raw and boiled. While high DNA yield was obtained using the alkaline-lysis method, PCR amplification was only successful on boiled samples. Lysis-buffer only method yielded in poor DNA quality and was not able to result in reliable DNA amplification.
\end{abstract}

Keywords: DNA extraction methods, halal, Porcine food contaminants.

\section{INTRODUCTION}

The consumption of meat products as a food staple was regulated in several major religions (e.g. Islam, Christianity and Judaism) mainly in the form of prohibitive consumption of porcine meat [1]. In many countries, a commitment to this principle is by the certification of meat products being sold to consumers by religious or government bodies, in which food free from porcine products is deemed halal in Islamic regulation, or kosher in Judaism. Unfortunately, contamination of porcine meat in halal-certified has been shown to occur in several countries, including Indonesia [2,3].

Detection of porcine meat product can be accomplished using several different methods. Commonly used, due to its high sensitivity and specificity, are DNA amplification methods, such as PCR [4,5,6]. However, this method, while reliable, has some drawbacks. Firstly, PCR method requires special equipment and relatively costly reagents, although cheaper than other methods [7]. Secondly, conventional DNA isolation methods (such as phenol-chloroform

\footnotetext{
* Correspondence address:

Arif Yahya

Email : cakyahu@yahoo.com

Address : Medical Faculty, Islamic University of Malang, MT Haryono 193, Malang 65144
}

isoamyl-alcohol or $\mathrm{PCl}$ ) are also costly, laborintensive, time-consumptive, and requires toxic chemicals [8]. Thus, while having a high reliability, these methods are prohibitive to be used on a day to day basis.

Several DNA isolation methods which are less time-consuming or costly has been attempted and published. While conventionally a kit is used to isolate DNA, one researcher reported the use of its accompanying lysis buffer with successful DNA amplification, cutting the DNA isolation time to 20 minutes after overnight incubation for preparation [9]. Other researchers have attempted to isolate DNA using an alkaline-lysis method, which uses a simple heat and alkaline treatment method to lyse the cells and isolate the DNA $[8,10]$. While these two methods have shown success in DNA isolation and PCR amplification for detection in raw meat, its reliability compared side by side to the established kit and conventional $\mathrm{PCl}$ has not been explored.

Furthermore, detection of porcine contamination in meat products is a more important issue. In this case, heat treated meat, for instance, could potentially damage DNA and complicate the detection for porcine contamination [7]; although DNA was shown to be resilient to heat damage [11]. However, the effectiveness of current DNA isolation protocols, 
as well as novel and rapid isolation methods, on heat-treated meat had not been compared. Therefore, in this study, we attempt to compare DNA isolation methods in the quantity and quality of extracted DNA and its success in PCR amplification for the detection of porcine material in raw and boiled meat.

\section{MATERIALS AND METHODS \\ Samples Preparation}

Bovine and Porcine meat samples was purchased from a local market in Malang, Indonesia. Meat samples were weighed to approximately 50 $\mathrm{g}$ before further handling and stored at $-20^{\circ} \mathrm{C}$ until use. These samples were separated into two groups: a raw meat and a boiled meat group. Bovine and Porcine meats were mixed with tapioca flour with a 10:1 ratio (meat g. flour g-1), and left for 15 minutes in boiling water, to stimulate the creation of meatballs. Both raw and boiled meat was weighed at $80 \mathrm{~g}$ and $150 \mathrm{~g}$ and distributed in $1.5 \mathrm{~mL}$ microtube for DNA extraction.

\section{DNA Extraction Protocols}

Samples were subjected to four DNA extraction and purification methods: a conventional $\mathrm{PCl}$ method [12], isolation kit method, alkaline-lysis method [9], and a lysisbuffer only method [10], in 6 replicates. Each method was validated using quantitative method (Nanodrop Spectrophotometer ND-1000). DNA extraction and PCR amplification were conducted in Central Laboratory for Life Science (LSIH), University of Brawijaya, Malang, Indonesia.

\section{Conventional PCI Method}

Modified from Erwanto et al [3], DNA was extracted by addition of $150 \mathrm{mg}$ of sample with $500 \mu \mathrm{L}$ TNE buffer, $50 \mu \mathrm{L}$ SDS $10 \%$ and $10 \mu \mathrm{L}$ Proteinase $\mathrm{K}$ and incubated at $42^{\circ} \mathrm{C}$ for 18 hours. Following this, $40 \mu \mathrm{L}$ phenol $(\mathrm{pH} 8.0), 5 \mu \mathrm{L} \mathrm{NaCl}$ $5 \mathrm{M}$, and $400 \mu \mathrm{L} \mathrm{PCl} \mathrm{(pH} \mathrm{8.0)} \mathrm{was} \mathrm{added} \mathrm{and}$ incubated at $37^{\circ} \mathrm{C}$ for 1 hour. The solution was centrifuged (Sigma-Santorius 318K) at $3000 \mathrm{rpm}$ for 5 minutes in room temperature, and the supernatant was transferred and added with 50 $\mu \mathrm{L}$ of $\mathrm{NaCl} 5 \mathrm{M}$ and $800 \mu \mathrm{L}$ of ethanol and incubated in $-20^{\circ} \mathrm{C}$ for 1.5 hours. DNA was retrieved by centrifugation at $8000 \mathrm{rpm}$ for five minutes in $4^{\circ} \mathrm{C}$. The resulting pellet was added with $600 \mu \mathrm{L}$ absolute ethanol, $300 \mu \mathrm{L}$ ammonium acetate $5 \mathrm{M}$, and $500 \mu \mathrm{L}$ TB buffer and incubated at $-20^{\circ} \mathrm{C}$ for ten minutes, before a final centrifugation at $13.000 \mathrm{rpm}$ for five minutes in $4^{\circ} \mathrm{C}$. Dried pellets were eluted using $50 \mu \mathrm{L}$ of $\mathrm{TE}$ buffer.

\section{Isolation Kit Method}

The isolation kit used in this method was the Jena Bioscience DNA Isolation Kit (Jena Bioscience, Jena, Germany). Samples were first aliquoted at $80 \mathrm{mg}$ in microtubes, and DNA extraction method was following manufacturer's instructions.

\section{Alkaline Lysis Method}

Modified from Buntjer et al [10], each sample was added with $2 \mathrm{~mL} \mathrm{NaOH}$ (0.5 M per gram), vortexed and incubated at $100^{\circ} \mathrm{C}$ for 10 minutes. The resulting solution was centrifuged at 13.000 rpm for 2 minutes at $37^{\circ} \mathrm{C}$ twice, with supernatant transferred into a new microtube each time. The supernatant was then added with ammonium acetate $5 \mathrm{M}$ at 0.5 times volume, added with absolute ethanol at 2-3 times volume, and incubated at $-20^{\circ} \mathrm{C}$ for 15 minutes. The solution was centrifuged for at $13.000 \mathrm{rpm}$ for five minutes to obtain pellets which were then washed using $500 \mu \mathrm{L}$ of $70 \%$ ethanol and recentrifuged at the same settings. Elution was done in $100 \mu \mathrm{L}$ TE buffer.

\section{Lysis-Buffer Only (Modified ASL Method)}

Modified from Alaraidh [9], each sample (80 $\mathrm{mg}$ ) was extracted using the lysis buffer provided in the Jena Bioscience DNA isolation kit. Each sample was added with $300 \mu \mathrm{L}$ lysis buffer and 2 $\mu \mathrm{L}$ RNase $\mathrm{A}$, and vortexed prior to $8 \mu \mathrm{L}$ proteinase $\mathrm{K}$, and incubated at $60^{\circ} \mathrm{C}$ for 5 minutes. The mix was then added with $300 \mu \mathrm{L}$ binding buffer, and placed on ice for 5 minutes before centrifugation at $10000 \mathrm{~g}$ for 5 minutes. The supernatant was transferred into a spin column for purification, following instruction from the manufacturers. DNA was eluted using a $50 \mu \mathrm{L}$ elution buffer and stored at $-20^{\circ} \mathrm{C}$.

\section{DNA Amplification Method}

The oligonucleotide primers [13], were synthesized by Integrated DNA Technology, Singapore. According to this study [13], oligonucleotides used were forward primer SIM 5'- GAC CTC CCA GCT CCA TCA AAC ATC TCA TCT TGA TGA AA -3', used for both porcine and bovine samples, and a bovine reverse primer 5'CTA GAA AAG TGT AAG ACC CGT AAT ATA AG -3' and porcine reverse primer 5' - GCT GAT AGT AGA TTT GTG ATG ACC GTA-3'. The amplicon length for porcine samples and bovine samples would be $398 \mathrm{bp}$ and $274 \mathrm{bp}$, respectively. 

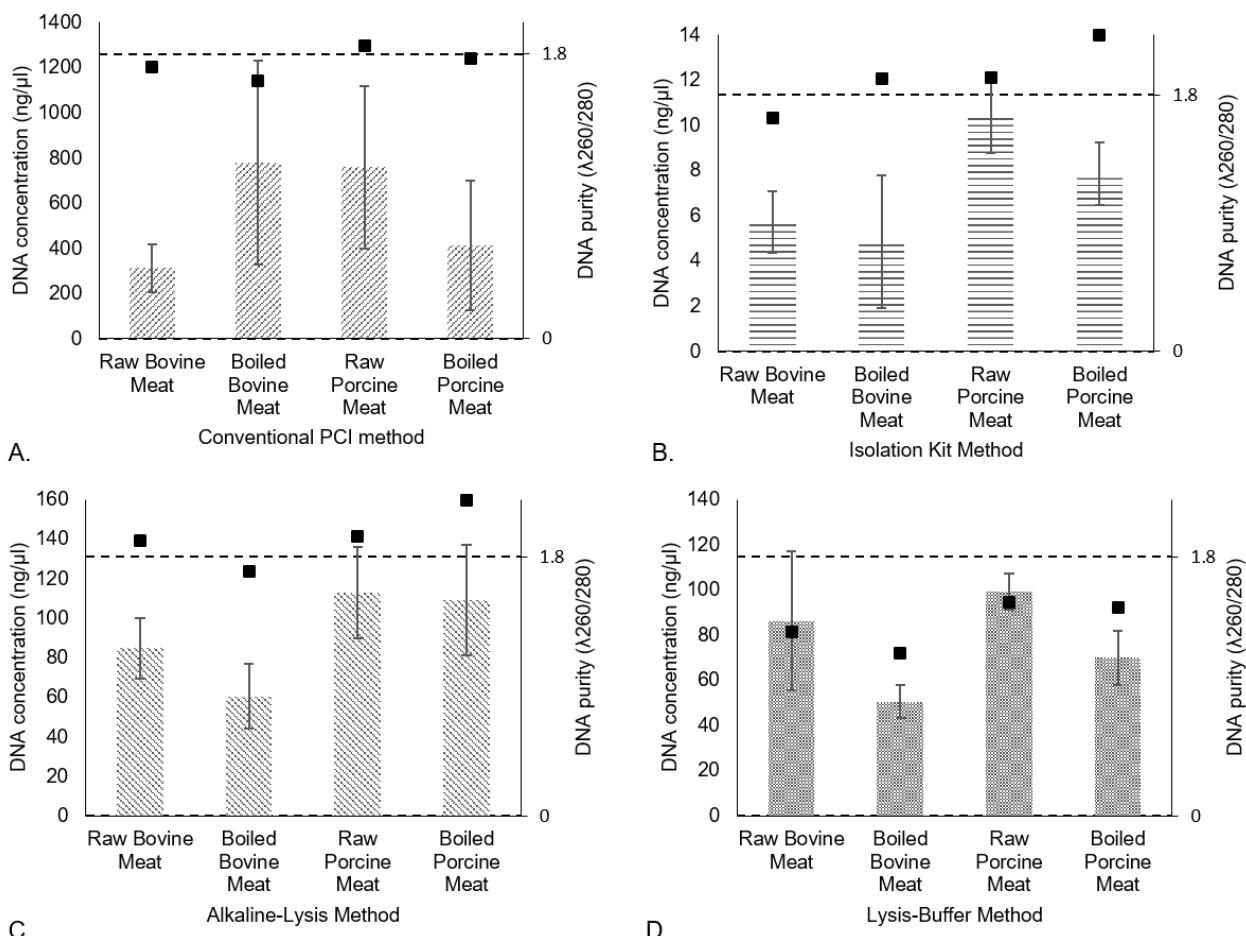

Figure 1. DNA yield and quality (denoted by symbol a) from A. conventional PCl method, B. isolation kit, C. alkaline-lysis, and D. lysis buffer method. The conventional method showed very high yield and good DNA quality in all samples.

The annealing temperature of these primers was optimised for both porcine and bovine samples using DNA samples obtained from $\mathrm{PCl}$ method. For porcine samples, five temperatures were tested, whilst seven temperatures were tested for bovine samples. The optimum annealing temperature was determined to be $64^{\circ} \mathrm{C}$ for bovine samples and $58^{\circ} \mathrm{C}$ for porcine samples (data not shown).

DNA amplification was carried out using five $\mu \mathrm{L}$ Go-Taq PCR mix, $0.5 \mu \mathrm{L}$ for each forward and reverse primers, three $\mu \mathrm{L}$ of nuclease-free water, and one $\mu \mathrm{L}$ of the DNA samples itself. PCR was carried out with a 5 minute $95^{\circ} \mathrm{C}$ pre-heating prior to 35 cycles of amplification for bovine samples ( 30 seconds at $94^{\circ} \mathrm{C}, 30$ seconds at $64^{\circ} \mathrm{C}$, and 45 seconds at $72^{\circ} \mathrm{C}$ ) and porcine samples ( 30 seconds at $94^{\circ} \mathrm{C}, 30$ seconds at $58^{\circ} \mathrm{C}$, and 45 seconds at $72^{\circ} \mathrm{C}$ ).

\section{Detection of Amplified Products}

PCR products were analysed using electrophoresis using a $1.5 \%$ Agarose gel. DNA band imaging was performed using a Gel Doc.

\section{RESULT AND DISCUSSION}

Conventional PCI Method Showed Reliable DNA Isolation Compared to Other Methods

A comparison of DNA yield and DNA quality (as measured by Nanodrop) obtained using the methodology previously described is shown in Figure 1 , with good DNA quality defined as having a $\lambda 260 / 280$ of $1.8-2.0$, as described in a previous literature [14].

Conventional $\mathrm{PCl}$ method was found to have the highest DNA yield with an average concentration of $566.16 \pm 370.05 \mathrm{ng} \cdot \mu \mathrm{L}^{-1}$ (up to 60 times of other methods), while also having a good quality with an average quality for all samples of $1.74 \pm 0.12$. On the other hand, both alkaline lysis and lysis-buffer method showed good DNA yield $\left(91.78 \pm 29.32 \mathrm{ng} \cdot \mu \mathrm{L}^{-1}\right.$ and $76.45 \pm 24.73 \mathrm{ng} \cdot \mu_{\mathrm{L}}^{-1}$, respectively), with good quality for alkaline lysis method $(1.94 \pm 0.31)$ and a very low quality for lysis-buffer method (1.34 \pm 0.17$)$. Lastly, isolation kit yielded the lowest DNA concentration (averaging at $7.21 \pm 2.85 \mathrm{ng}^{\prime \mu} \mathrm{L}^{-1}$ ), although having a good DNA quality $(1.92 \pm 0.39)$.

Overall, based on DNA yield and quality of the control methods ( $\mathrm{PCl}$ and isolation kits), these findings suggest that conventional $\mathrm{PCl}$ method was the most reliable method for DNA extraction, with high concentration obtained from raw and boiled porcine or bovine meat. These results support previous findings, as $\mathrm{PCl}$ method has been used in many DNA isolation studies in this field $[3,7,12,15]$. Compared to $\mathrm{PCl}$ method, isolation kit method showed relatively low DNA yield, albeit having good DNA quality. These results 
were also concurrent with many researchers in this field, whereas DNA yield in various kit assays was often shown to be significantly lower compared PCl method [16]. PCR amplification, however, seems to be dependent than other factors aside from high DNA yield, whereas PCR amplification was shown to be successful on DNA yield as low as five ng. $\mu \mathrm{L}^{-1}$ [17].

As for the unconventional methods tested in this study, alkaline-lysis method showed good reliability in DNA extraction for these samples, while lysis buffer method showed good DNA isolation, albeit having poor quality. Results from alkaline-lysis method used in this study showed comparable DNA yield from other studies using similar methods [8], and higher than the original method [10]. Lysis-buffer only method differed from the previous article, in which a DNAzol ${ }^{\circledR}$ Direct from Qiagen was used; however, the DNA isolation yield quality was not reported [9].

\section{PCR Amplification Showed Varied Results De- pending on DNA Isolation Method}

PCR amplification results summarized in table 1. Amplification was conducted on a cytochrome $b$ gene with a common forward primer and specific reverse primers, as first described previous literature [18]. The size calculated from these samples were different than previously reported [13], whereas bovine samples, a band size of 320 bp was calculated, and from porcine samples a band size of $360 \mathrm{bp}$ was calculated.

Table 1. Summary of PCR amplification from raw and boiled bovine and porcine meat samples

\begin{tabular}{lcc}
\hline $\begin{array}{c}\text { DNA isolation } \\
\text { method }\end{array}$ & Samples & $\begin{array}{c}\text { Positive } \\
\text { results/ } \\
\text { replicate }\end{array}$ \\
\hline Conventional (PCI) & Raw bovine meat & $2 / 3$ \\
& Boiled bovine meat & $3 * / 3$ \\
& Raw porcine meat & $3 / 3$ \\
& Boiled porcine meat & $3 / 3$ \\
\hline Isolation Kit & Raw bovine meat & $3 / 3$ \\
& Boiled bovine meat & $2 / 3$ \\
& Raw porcine meat & $3 / 3$ \\
& Boiled porcine meat & $3 / 3$ \\
\hline Alkaline-lysis & Raw bovine meat & $3 * / 3$ \\
& Boiled bovine meat & $3 / 3$ \\
& Raw porcine meat & $1 * / 3$ \\
& Boiled porcine meat & $3 / 3$ \\
\hline Lysis-Buffer Only & Raw bovine meat & $0 / 3$ \\
& Boiled bovine meat & $1 / 3$ \\
& Raw porcine meat & $2 * / 3$ \\
& Boiled porcine meat & $3 * / 3$ \\
\hline
\end{tabular}

Notes: $\left({ }^{*}\right)$ denotes hazy, unclear, or weak bands

Based on this study, conventional and isolation kit method showed a 92\% PCR amplification from all samples. Alkaline-lysis success in amplifi- cation was $83 \%$, and lysis-buffer method had only a $50 \%$ chance. Control methods, therefore, showed more reliability in the detection of porcine and bovine samples, and alkaline-lysis had a higher chance of detection compared to the lysisbuffer method. It should be noted that while some bands were unclear/weak, all bands showed the same band size corresponding to bovine and porcine samples.

Previous research has noted the importance of DNA isolation methods in successfully amplifying a DNA product $[16,17]$, in which this research also concurs. Amplification failure may occur in samples having high PCR inhibitors, including various proteins found in meat samples, as described elsewhere [19]. While both conventional and isolation kit methods provide efforts to minimalize these inhibitors, unconventional methods used in this study do not. Therefore, the presence of these inhibitors may explain the low reliability in using lysis-buffer method for PCR amplification, in which false negatives occurred. Similarly, this may also explain the increased amplification of gene products using the alkaline-lysis method on boiled meats, whereas previous studies indicate that boiling as an inexpensive method to remove PCR inhibitors [20].

\section{CONCLUSION}

Conventional methods for DNA isolation in this study, which was PCl method and isolation kit method, showed high reliability in detection of bovine and porcine meat samples, both raw and boiled for a short time; despite the low DNA yield for isolation kit method. In the unconventional method tested in this study, DNA isolation using alkaline-lysis method resulted in a higher reliability in PCR amplification on boiled samples compared to raw samples, while also having a high DNA yield and good DNA quality. On the other hand, lysis-buffer method only showed poor results in DNA isolation as well as PCR amplification.

\section{ACKNOWLEDGEMENT}

We acknowledge Indonesian Ministry of Research, Technology and Higher Education (RISTEK-DIKTI) for the funding of this research from PDP research scheme.

\section{REFERENCES}

[1] Fadzlillah, N.A., Y.C. Man, M.A. Jamaludin, S. Ab.Rahman, H.A. Al-Kahtani. 2011. Halal food issues from Islamic and modern science perspectives. $2^{\text {nd }}$ Int. Conf. Humanit. Hist. Soc. Sci. 17. 159-163. 
[2] Farouk, A.E., M.F. Batcha, R. Greiner, H.M. Salleh, M.R. Salleh, A.R. Sirajudin. 2006. The use of a molecular technique for the detection of porcine ingredients in the Malaysian food market. Saudi Med. J. 27(9). 1397-1400.

[3] Erwanto, Y., M.Z. Abidin, E.Y.P.M. Sugiyono, A. Rohman. 2014. Identification of pork contamination in meatballs of Indonesia local market using Polymerase Chain Reaction-Restriction Fragment Length Polymorphism (PCR-RFLP) analysis. AsianAustralasian J. Anim. Sci. 27(10). 14871492.

[4] Plath, A., I. Krause, R. Einspannier. 1997. Species identification in dairy products by three different DNA-based techniques. $Z$ Leb Unters Forsch A. 205. Available at: https://doi.org/10.1007/s002170050195.

[5] Wolf, C., J. Rentsch, P. Hubner. 1999. PCRRFLP analysis of mitochondrial DNA: a reliable method for species identification. J. Agric. Food Chem. 47. Available at: https://doi.org/10.1021/jf9808426.

[6] Pfeiffer, I., J. Burger, B. Brenig. 2004. Diagnostic polymorphisms in the mitochondrial cytochrome b gene allow discrimination between cattle, sheep, goat, roe buck and deer by PCR-RFLP. BMC Genet. 5(1). 30.

[7] Farag, M.R., M. Alagawany, M. Ezzat Abd ElHack, R. Tiwari, K. Dhama. 2015. Identification of different animal species in meat and meat products: trends and advances. Adv. Anim. Vet. Sci. 3(6). 334-346.

[8] Girish, P.S., S. Haunshi, S. Vaithiyanathan, R. Rajitha, C. Ramakrishna. 2013. A rapid method for authentication of Buffalo (Bubalus bubalis) meat by Alkaline Lysis method of DNA extraction and species specific polymerase chain reaction. J. Food Sci. Technol. 50(1). 141-146.

[9] Alaraidh, I.A. 2008. Improved DNA extraction method for porcine contaminants, detection in imported meat to the Saudi market. Saudi J. Biol. Sci. 15(152). 225-229.

[10] Buntjer, J.B., J.A. Lenstra, N. Haagsma. 1995. Rapid species identification in meat by using satellite DNA probes. Zeitschrift f\{ü\}r Leb und Forsch. 201(6). 577-582.

[11] Arslan, A., O.I. Ilhak, M. Calicioglu. 2006. Effect of method of cooking on identification of heat processed beef using polymerase chain reaction (PCR) technique. Meat Sci. 72(2). 326-330.

[12] Erwanto, Y., M.Z. Abidin, X. Sismindari, A. Rohman. 2012. Pig species identification in meatballs using polymerase chain reactionrestriction fragment length polymorphism for Halal authentication. Int. Food Res. J. 19(3). 901-906.

[13] Di Pinto, A., M. Bottaro, E. Bonerba, G. Bozzo, E. Ceci, P. Marchetti, et al. 2015. Occurrence of mislabeling in meat products using DNA-based assay. J. Food Sci. Technol. 52(4). 2479-2484.

[14] Sambrook, J., D.W. Russell. 2001. Molecular cloning - Sambrook \& Russel - Vol. 1, 2, 3. Vol. 18, CSH Press. Cold Spring Harbor Laboratory Press.

[15] Cai, Y., Y. He, R. Lv, H. Chen, Q. Wang, L. Pan. 2017. Detection and quantification of beef and pork materials in meat products by duplex droplet digital PCR. PLoS One. 12(8). 1-12.

[16] Djurkin-Kusec, I., Z. Radisic, M. Komlenic, G. Kusec. 2015. Comparison of commercial DNA kits and traditional DNA extraction procedure in PCR detection of pork in dry/fermented sausages. Poljoprivreda/Agr. 21(1 Supplement). 199-202.

[17] Myers, M.J., D.E. Farrell, C.M. Deaver, J. Mason, H.L. Swaim, H.F. Yancy. 2010. Detection of rendered meat and bone meals by PCR is dependent on animal species of origin and DNA extraction method. J. Food Prot. 73(6). 1090-1096.

[18] Matsunaga, T., K. Chikuni, R. Tanabe, S. Muroya, K. Shibata, J. Yamada, et al. 1999. A quick and simple method for the identification of meat species and meat products by PCR assay. Meat Sci. 51(2). 143148.

[19] Schrader, C., A. Schielke, L. Ellerbroek, R. Johne. 2012. PCR inhibitors - occurrence, properties and removal. J. Appl. Microbiol. 113(5). 1014-1026.

[20] Böddinghaus, B., T.A. Wichelhaus, V. Brade, T. Bittner. 2001. Removal of PCR inhibitors by silica membranes: evaluating the Amplicor Mycobacterium tuberculosis Kit. J. Clin. Microbiol. 39(10). 3750-3752. 